\title{
Correlation of Patient Generated-subjective Global Assessment with Serum C-reactive Protein Level in Stage I-IV Head-and-neck Cancer
}

\author{
Anastasya Siregar ${ }^{1 *}$ (D), Dian Novita Chandra ${ }^{1}\left(\mathbb{D}\right.$, Ikhwan Rinaldi $^{2 *}$ (D) \\ ${ }^{1}$ Department of Nutrition, Faculty of Medicine, Universitas Indonesia, Cipto Mangunkusumo National General Hospital, Jakarta, \\ Indonesia; ${ }^{2}$ Department of Internal Medicine, Division of Hematology and Medical Oncology, Faculty of Medicine, Universitas \\ Indonesia, Cipto Mangunkusumo National General Hospital, Jakarta, Indonesia
}

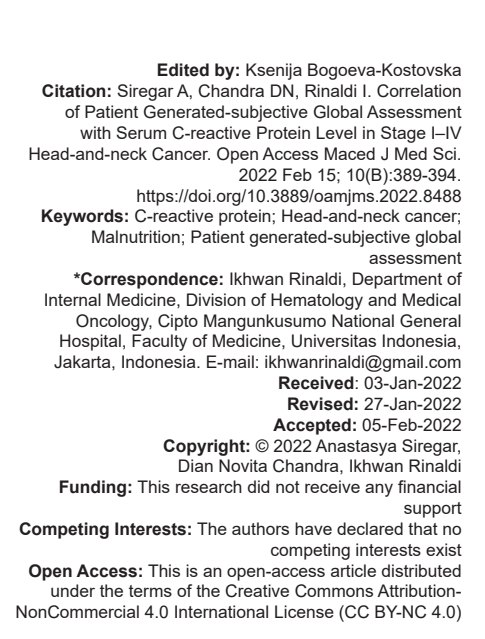

\section{Abstract}

AIM: This study aims to identify the correlation between patient generated-subjective global assessment (PG-SGA) with serum C-reactive protein (CRP) to be used to predict inflammation and prevent cachexia in head-and-neck cancer patients.

METHODS: This was a cross-sectional study using 51 patients with inclusion criteria of patients diagnosed with head-and-neck cancer irrespective of stage, age $\geq 18$ years old, had not received treatments of radiotherapy, chemotherapy, and surgery. The statistical analysis performed was Kolmogorov-Smirnov normality test, bivariate analysis by Spearman test, and linear regression analysis.

RESULTS: As many as $64.7 \%$ of the patients had PG-SGA score $\geq 9$ (average PG-SGA score $11.7 \pm 6.2$ ). The CRP median value was $6.4(0.4-170.4) \mathrm{mg} / \mathrm{L}$. There was a statistically significant positive but weak correlation between PG-SGA score with serum CRP $(r=0.372$ and $p=0.007)$ and a significant linear relationship $\left(r^{2}=0.201\right)$.

CONCLUSIONS: Malnutrition risk assessment using PG-SGA showed a high prevalence of malnutrition risk in headand-neck cancer patients. PG-SGA score is correlated with serum CRP level. Further studies are needed to confirm the result of this study.

\section{Introduction}

Nutrition is one of the most crucial aspects in the management of cancer patients, especially regarding malnutrition and cachexia [1]. According to the European Society of Clinical Nutrition and Metabolism (ESPEN), malnutrition is defined as "a state resulting from lack of intake or uptake of nutrition that leads to altered body composition (decreased fat free mass) and body cell mass leading to diminished physical and mental function and impaired clinical outcome from disease," which may be caused by disease accompanied by inflammation [2]. The prevalence of malnutrition in cancer patients is high with studies from South Korea, Australia, China, and Brazil showing malnutrition prevalence of $22 \%$, $26 \%, 41.3 \%$, and $45.3 \%$, respectively [3], [4], [5], [6]. Meanwhile, estimates from a systematic review for the prevalence of cachexia in cancer patients are 30.0\% for Europe and $30.1 \%$ for U.S. population [7].

The prevalence of nutritional deficiency or malnutrition to cachexia in the head-and-neck cancer reached $35-60 \%$ [8]. Based on a study by Hebuterne et al., malnutrition in head-and-neck cancer $(48.9 \%)$ was in third place after pancreatic cancer (66.67\%), esophageal, and/or gastric cancer (60.2\%) [9]. Malnutrition and cancer cachexia will increase healthcare costs, lower immunity, slow down wound healing, and affect treatment outcomes [10]. Furthermore, malnutrition is associated with an increases risk of complications and mortality [11], [12].

Malnutrition or cancer cachexia is caused by interaction between the tumor, host, or other factors. The interaction between the tumor and host factor caused systemic inflammation response marked by an increase in pro-inflammatory cytokines. These cytokines will eventually stimulate hepatocyte cells to produce acute phase protein such as C-reactive protein (CRP) in which CRP synthesis requires a number of amino acids which can be derived from the skeletal muscles which causes wasting. Hence, CRP not only can act as a systemic inflammation marker, but may also be used as an indicator which plays a role in the development of malnutrition and cachexia [6], [7]. In addition, pro-inflammatory cytokines 
such as CRP may also contribute to increased risk of death from cachexia [13]. Therefore, there is a need to assess malnutrition risk and the nutritional status in cancer patients as early as possible [10].

Malnutrition in cancer is the best prevented by performing a malnutrition screening followed by nutritional therapy. The guidelines from ESPEN recommended some screening tools to assess the malnutrition risk such as the malnutrition universal screening tool, nutritional risk screening-2002, mini nutritional assessment, subjective global assessment (SGA), and patient generatedSGA (PG-SGA). However, the malnutrition screening recommended by the Oncology Nutrition Dietetic Practice Group of the Academy of Nutrition and Dietetics (formerly American Dietetic Association) and has been validated in cancer patients is PG-SGA [14]. Nutritional deficiency cannot be diagnosed based on only a single parameter, such as only assessing body weight, decrease in muscle mass or subcutaneous fat, fluid accumulation, and decrease in daily functional ability. Although body weight is one of the simple anthropometric parameters especially when used for population, the assessment in cancer patients can be affected by the change in fluid distribution due to ascites, edema, and dehydration [10], [15].

Until now, in Indonesia, there has not been any data on the use of PG-SGA score as a tool to assess malnutrition risk in head-and-neck cancer patients. In addition, the increase of CRP has been shown to have independent prognostic value in patients with locally advanced pancreatic cancer receiving radiotherapy (HR 2.2) [16], lung cancer and history of smoking (OR 1.63) [17], and advanced cancer in palliative care (moderate-, high-, and very high CRP: HR 1.47, 2.09, and 2.55) [18]. Therefore, we conducted this study on the correlation between PG-SGA score with serum CRP in newly diagnosed head-and-neck cancer patient Stage I-IV at Cipto Mangunkusumo National General Hospital.

\section{Methods}

\section{Study design}

This was a cross-sectional study using consecutive sampling method which was conducted from May 2016 to August 2016 at Cipto Mangukusumo National General Hospital Jakarta. All data were obtained from patients using interview, while cancer location and stage were obtained from medical record.

The malnutrition risk assessment was conducted using PG-SGA which was divided into seven boxes. The study subjects filled out the PG-SGA form in box 1-4 while box 5-7 was filled out by the researcher together with the physical examination. The physical examination included a subjective assessment from three aspects of body composition consisting of fat reserve, muscle state, and fluid state. Body temperature measurement using a mercury thermometer is also conducted to assess body metabolic stress in PG-SGA.

The result of the assessment is the sum of all scores in each question and from the physical examination with scores ranging from 0 to 47 . The researcher also conducted an anthropometric examination, body weight measurement with electro digital scale Seca Alpha Hamburg-Germany, and height measurement using Microtoise Stature Meter $2 \mathrm{~m}$. The procedure of measuring weight and height was repeated twice and the results were then averaged. The results were also used to measure body mass index (BMI). $\mathrm{BMI}$ is based on the classification for the Asia Pacific.

Afterward, we conducted a laboratory examination to examine the serum CRP. A blood sample was taken by the laboratory officer at the Laboratory Unit in the Integrative Outpatient Unit third floor Cipto Mangunkusumo Hospital Jakarta. The $1 \mathrm{ml}$ blood sample was taken from the cubital vein and placed into the vacutainer tube without coagulant factor. The serum CRP calculation used the immunoturbidimetry method, and its interpretation is stated in $\mathrm{mg} / \mathrm{L}$.

\section{Patients}

The inclusion criteria for this cross-sectional study were patients diagnosed with head-and-neck cancer irrespective of stage, age $\geq 18$ years old, had not received treatments of radiotherapy, chemotherapy, and surgery. In addition, only patients that stated his/ her willingness to participate in the study and signed an informed consent letter were included in the study. Exclusion criteria were non-cooperative subjects and those who cannot speak Indonesian language.

The number of samples needed based on calculation was 52 people. This is based on a study by Read et al. which found a positive correlation with moderate strength between PG-SGA score and CRP in 51 stage IV colorectal cancer subjects ( $r$ : 0.430 and p: 0.003) [19]. With additional calculations using the correlation formula, we found that we needed 47 samples but to avoid not reaching the response rate, we added $10 \%$ to the sample size, and decided on the target of 52 people.

\section{Ethics}

The research protocol had gained approval from the Research Ethics Committee, Faculty of Medicine, Universitas Indonesia (No. 202/UNF1/ETIK/2016). This study is in compliance with Declaration of Helsinki.

\section{Statistical analysis}

The data analysis was conducted using Statistical Package for the Social Sciences program 
version 20. The normality of data distribution was analyzed using the Kolmogorov-Smirnov test. Data with a normal distribution $(p>0.05)$ were presented in the form of mean and standard deviation (SD) while data with non-normal distribution $(p<0.05)$ were presented as median and range (minimum-maximum). Meanwhile, categorical data were presented using frequency with percentages. Bivariate analysis with Spearman test was conducted to assess the correlation between PG-SGA score with serum CRP continued with simple linear regression analysis. Statistical analysis used a confidence level of $95 \%$ and significance level $p<0.05$.

\section{Results}

The number of analyzed subjects in this study was only 51 subjects because one subject had not yet completed the cancer stage determination. Table 1 shows the distribution of study subjects based on demographic characteristics including age, sex, education level, income level, and clinical conditions including location, stage of cancer, and anthropometry.

The study results showed that the average age was $46.6 \pm 13.9$ years old. Most subjects were male (39 subjects, $76.5 \%$ ). The most common cancer location

Table 1: Distribution of subjects based on demography and clinical characteristics $(n=51)$

\begin{tabular}{|c|c|}
\hline Variable & Value \\
\hline Age (year) & $46.6 \pm 13.99^{*}$ \\
\hline \multicolumn{2}{|l|}{ Age category, n (\%) } \\
\hline$>18-45$ years old & $22(43.1)$ \\
\hline $45-59$ years old & $20(39.2)$ \\
\hline$\geq 60$ years old & $9(17.6)$ \\
\hline \multicolumn{2}{|l|}{ Sex, n (\%) } \\
\hline Male & $39(76.5)$ \\
\hline Female & $12(23.5)$ \\
\hline \multicolumn{2}{|l|}{ Education level, n (\%) } \\
\hline Low & $25(49)$ \\
\hline Medium & $17(33.3)$ \\
\hline High & $9(17.6)$ \\
\hline \multicolumn{2}{|l|}{ Income level, n (\%) } \\
\hline Below minimum wage & $36(70.6)$ \\
\hline Above minimum wage & $15(29.4)$ \\
\hline \multicolumn{2}{|l|}{ Cancer location, n (\%) } \\
\hline Nasopharynx & $41(80.4)$ \\
\hline Larynx & $8(15.7)$ \\
\hline Hypopharynx & $1(2)$ \\
\hline Sinonasal & $1(2)$ \\
\hline \multicolumn{2}{|l|}{ Cancer stage, $\mathrm{n}(\%)$} \\
\hline I & - \\
\hline II & $2(3.9)$ \\
\hline III & $4(7.8)$ \\
\hline IVA & $30(58.8)$ \\
\hline IVB & $5(9.8)$ \\
\hline IVC & $10(19.6)$ \\
\hline \multicolumn{2}{|c|}{ Based on two categories of cancer stage, $n(\%)$} \\
\hline Stage I and II & $2(3.9)$ \\
\hline Stage III and IV & $49(96.1)$ \\
\hline \multicolumn{2}{|l|}{ Anthropometry } \\
\hline Body weight (kg) & $53.4 \pm 11.51^{*}$ \\
\hline Height $(\mathrm{cm})$ & $160.9 \pm 7.48^{*}$ \\
\hline Body mass index $\left(\mathrm{kg} / \mathrm{m}^{2}\right)$ & $20.6 \pm 4.04^{*}$ \\
\hline \multicolumn{2}{|c|}{ Body mass index classification, $\mathrm{n}(\%)$} \\
\hline Low body weight & $18(35.3)$ \\
\hline Normal body weight & $19(37.3)$ \\
\hline Overweight & $7(13.7)$ \\
\hline Grade 1 obesity & $6(11.8)$ \\
\hline Grade 2 obesity & $1(2)$ \\
\hline
\end{tabular}

is in the nasopharynx, (41 subjects, $80.4 \%$ ) followed by the larynx ( 8 subjects, $15.7 \%$ ). Stage IVA was the most common (30 subjects, $58.8 \%$ ) and III and IV stage cancer was the most often (49 subjects, $96.1 \%$ ) when based only on two main categories for cancer stage. The BMI of study subjects was mostly normal body weight (19 subjects, $37.3 \%$ ).

The mean PG-SGA score was $11.7 \pm 6.2$ and most subjects had PG-SGA $\geq 9(64.7 \%)$ in Table 2 . The median value of serum CRP for all study subjects was $6.4 \mathrm{mg} / \mathrm{L}$, ranging from 0.4 to $170.4 \mathrm{mg} / \mathrm{L}$.

Table 2: Characteristics based on PG-SGA score $(n=51)$

\begin{tabular}{ll}
\hline Variable & Score \\
\hline PG-SGA score & $11.7 \pm 6.2^{*}$ \\
Nutrition triage recommendation score, $\mathrm{n}(\%)$ & - \\
$0-1$ & $5(9.8)$ \\
$2-3$ & $13(25.5)$ \\
$4-8$ & $33(64.7)$ \\
$\geq 9$ &
\end{tabular}

\section{The correlation between PG-SGA score and serum CRP level}

Table 3 shows that there is a statistically significant positive correlation between PG-SGA score with serum CRP level. The coefficient from Spearman test was 0.372 which indicated a weak correlation.

Table 3: Correlation between PG-SGA score with serum CRP level $(n=51)$

\begin{tabular}{lll}
\hline Variable & PG-SGA Score & \\
\cline { 2 - 3 } & $\mathrm{r}$ & $\mathrm{p}$-value \\
\hline Serum CRP & $0.372^{\ddagger}$ & 0.007 \\
\hline${ }^{\ddagger}$ Spearman correlation test, CRP: C-reactive protein. &
\end{tabular}

Afterward, we performed a simple linear regression analysis and found the determination coefficient value or R square $\left(r^{2}\right)$ at 0.201 (Table 4). This value showed that the contribution or impact of total PG-SGA score variable toward the fluctuation of serum CRP level was $20.1 \%$.

Table 4: Linear regression of PG-SGA score with serum CRP level $(n=51)$

\begin{tabular}{llll}
\hline Variable & \multicolumn{2}{l}{ Serum CRP level } & \\
\cline { 2 - 4 } & $\mathrm{r}^{2}$ & $\mathrm{~B}$ & $\mathrm{p}$-value \\
\hline PG-SGA & 0.201 & 0.499 & 0.01 \\
\hline PG-SGA: Patient generated-subjective global assessment. & &
\end{tabular}

\section{Discussion}

Results of PG-SGA score determine the recommendation of nutritional triage given to patients, in which, higher PG-SGA score correlates with higher risk of malnutrition. Score of $\geq 4$ indicated a need for nutritional and symptoms management, while PG-SGA Score $\geq 9$ indicated immediate nutrition management. The PG-SGA score accurately showed 
identification of a patient's good nutritional state and malnutrition with cutoff score at $\geq 9$ [20]. The percentage of high PG-SGA score in this study (PG-SGA score $\geq 9$ as many as $64.7 \%$ ) can be caused by anorexia and cachexia mechanism occurred in cancer patients causing massive body weight loss and lack of intake [21].

The study subjects had a median value of CRP at $6.4(0.4-170.4) \mathrm{mg} / \mathrm{L}$. The CRP results in this study are similar to the study by Orell-Kotinkangas et al. [20] on 65 head-and-neck Stage I-IV cancer subjects, which reported a median value of 6.0 (3-21). Factors that might affect different results from this study are that the study subjects were at a later stage of cancer and had a different type of cancers. The difference in CRP is also affected by cancer stage and location [22]. Besides that, the CRP value is correlated progressively with tumor size $(p<0.001)$, major lymph node $(p<0.001)$, and cancer stage $(p<0.001)$ [23].

\section{CRP level \\ Correlation of PG-SGA score with serum}

Based on the study results, we found a positive but weak correlation between PG-SGA score and serum CRP level. This is in accordance with the study by Read et al. on 51 Stage IV colorectal cancer patients, although most subjects had undergone chemotherapy, radiotherapy, and surgery [19]. The study by Read et al. found a positive correlation with moderate strength between the PG-SGA score and CRP ( $r$ : 0.430 and p: 0.003) [19]. Those results supported this study which also had a weak positive correlation value. In addition, based on the simple linear regression analysis, there is indication that CRP level is also caused by other factors besides the PG-SGA score.

There are many factors which may affect the correlation between PG-SGAscore with serum CRP such as age, cancer location, BMI, and existing chronic illness or comorbidities. Chronic illnesses such as diabetes mellitus, TB, chronic obstructive pulmonary disease, and cardiovascular disease can increase CRP level, affecting the nutritional state, and increase the risk of malnutrition or cancer cachexia [18], [22], [24], [25], [26], [27]. However, this study did not include comorbidities for the analysis. Finally, the presence of cancer may also impact CRP level [28].

One of the assessments in PG-SGA is the percentage of body weight loss. A study by Gomes et al. [29] on 30 subjects with Stage I-IV gastrointestinal cancer concluded that subjects with body weight loss and high risk for malnutrition based on PG-SGA score have significantly higher CRP level compared to subjects with good nutritional state and not experiencing any body weight loss. Other study results also are consistent such as the study by Capuano et al. [30] on 61 subjects with head-and-neck cancer with no history of surgery or prior oncology management. The results showed that there is a significant relationship between the PG-SGA score with CRP $(p<0.001)$. The study concluded that we need a preliminary nutritional assessment and therapy to decrease progressive body weight loss in headand-neck cancer patient.

\section{Study limitation}

Many factors can affect the PG-SGA score assessment, therefore, affecting the correlation result of this study. Filling out the PG-SGA form was subjective and can be affected by the ability to remember and the subject's cognitive ability. Moreover, CRP decrease occurred in patients using steroids and non-steroid anti-inflammatory drugs [22], [24]. Cancer mass can cause mechanical obstruction in the digestive tract causing dysphagia and difficulty in swallowing causing a decrease in food intake [31].

\section{Conclusion}

This study found that there is a statistically significant positive but weak correlation between PG-SGA score with serum CRP in patients with headand-neck cancer. Further studies are needed to confirm the role of PG-SGA with serum CRP.

\section{Acknowledgments for Research Support}

The authors would like to thank Dr.dr. Diana Sunardi, M.Gizi, SpGK, Dr.dr. Ninik Mudjihartini, MS, Prof.Dr.dr. Saptawati Bardosono, MSc, dr. Syahrial M.Hutahuruk, Sp.THT-KL $(\mathrm{K})$, and to the entire staff of the Department of Ear Nose Throat FMUI who had supported this study.

\section{References}

1. Ravasco P. Nutrition in cancer patients. J Clin Med 2019;8(8):1211. https://doi.org/10.3390/jcm8081211 PMid:31416154

2. Cederholm T, Bosaeus I, Barazzoni R, Bauer J, Van Gossum A Klek S, et al. Diagnostic criteria for malnutrition-an ESPEN consensus statement. Clin Nutr. 2015;34(3):335-40. https://doi. org/10.1016/j.clnu.2015.03.001 PMid:25799486

3. Kang MC, Kim JH, Ryu SW, Moon JY, Park JH, Park JK, et al. Prevalence of malnutrition in hospitalized patients: A multicenter 
cross-sectional study. J Korean Med Sci. 2018;33(2):e10. https://doi.org/10.3346/jkms.2018.33.e10

PMid:29215819

4. Marshall KM, Loeliger J, Nolte L, Kelaart A, Kiss NK. Prevalence of malnutrition and impact on clinical outcomes in cancer services: A comparison of two time points. Clin Nutr. 2019;38(2):644-51. https://doi.org/10.1016/j. clnu.2018.04.007

PMid:29789167

5. Li Z, Chen W, Li H, Chinese Oncology Nutrition Survey Group. Nutrition support in hospitalized cancer patients with malnutrition in China. Asia Pac J Clin Nutr. 2018;27(6):1216-24. https://doi. org/10.6133/apjcn.201811_27(6).0007

PMid:30485919

6. de Pinho NB, Martucci RB, Rodrigues VD, D'Almeida CA, Thuler LC, Saunders C, et al. High prevalence of malnutrition and nutrition impact symptoms in older patients with cancer: Results of a Brazilian multicenter study. Cancer. 2020;126(1):156-64. https://doi.org/10.1002/cncr.32437

PMid:31497875

7. Anker MS, Holcomb R, Muscaritoli M, von Haehling $S$, Haverkamp W, Jatoi A, et al. Orphan disease status of cancer cachexia in the USA and in the European Union: A systematic review. J Cachexia Sarcopenia Muscle. 2019;10(1):22-34 https://doi.org/10.1002/jcsm.12402

PMid:30920776

8. Alshadwi A, Nadershah M, Carlson ER, Young LS, Burke PA, Daley BJ. Nutritional considerations for head and neck cancer patients: A review of the literature. J Oral Maxillofac Surg. $\quad 2013 ; 71(11): 1853-60 . \quad$ https://doi.org/10.1016/j. joms.2013.04.028

PMid:23845698

9. Hébuterne $X$, Lemarié $E$, Michallet $M$, de Montreuil $C B$, Schneider SM, Goldwasser F. Prevalence of malnutrition and current use of nutrition support in patients with cancer. JPEN J Parenter Enteral Nutr. 2014;38(2):196-204. https://doi. org/10.1177/0148607113502674

PMid:24748626

10. Haghjoo S. Malnutrition associated with head and neck cancers. Rev Clin Med. 2015;2:76-9.

11. BarkerLA, GoutBS, Crowe TC. Hospital malnutrition: Prevalence, identification and impact on patients and the healthcare system. Int J Environ Res Public Health. 2011;8(2):514-27. https://doi. org/10.3390/ijerph8020514

PMid:21556200

12. Triarico S, Rinninella E, Cintoni M, Capozza MA, Mastrangelo S, Mele MC, et al. Impact of malnutrition on survival and infections among pediatric patients with cancer: A retrospective study. Eur Rev Med Pharmacol Sci. 2019;23(3):1165-75. https://doi. org/10.26355/eurrev_201901_17009

PMid:30779086

13. Kalantar-Zadeh K, Rhee C, Sim JJ, Stenvinkel P, Anker SD, Kovesdy CP. Why cachexia kills: Examining the causality of poor outcomes in wasting conditions. J Cachexia Sarcopenia Muscle. 2013;4(2):89-94. https://doi.org/10.1007/ s13539-013-0111-0

PMid:23749718

14. Gorenc M, Kozjek NR, Strojan P. Malnutrition and cachexia in patients with head and neck cancer treated with (chemo) radiotherapy. Rep Pract Oncol Radiother. 2015;20(4):249-58. https://doi.org/10.1016/j.rpor.2015.03.001

PMid:26109912

15. Shaw C, Fleuret C, Pickard JM, Mohammed K, Black G, Wedlake L. Comparison of a novel, simple nutrition screening tool for adult oncology inpatients and the malnutrition screening tool (MST) against the patientgenerated subjective global assessment (PG-SGA). Support Care Cancer. 2015;23(1):47-54. https://doi.org/10.1007/ s00520-014-2319-8

PMid:24947056

16. Naumann $P$, Eberlein J, Farnia B, Liermann J, Hackert $T$, Debus $\mathrm{J}$, et al. Cachectic body composition and inflammatory markers portend a poor prognosis in patients with locally advanced pancreatic cancer treated with chemoradiation. Cancers (Basel). 2019;11(11):1655. https://doi.org/10.3390/ cancers 11111655

PMid:31717736

17. Nagata M, Ito H, Matsuzaki T, Furumoto H, Isaka T, Nishii T, et al Body mass index, C-reactive protein and survival in smokers undergoing lobectomy for lung cancer. Eur J Cardiothorac Surg. 2017;51(6):1164-70. https://doi.org/10.1093/ejcts/ ezx004

\section{PMid:28199511}

18. Amano K, Maeda I, Morita T, Miura T, Inoue S, Ikenaga M, et al Clinical implications of $\mathrm{C}$-reactive protein as a prognostic marker in advanced cancer patients in palliative care settings. J Pain Symptom Manage. 2016;51:860-7. https://doi.org/10.1016/j. jpainsymman.2015.11.025

PMid:26826676

19. Read JA, Choy ST, Beale PJ, Clarke SJ. Evaluation of nutritional and inflammatory status of advanced colorectal cancer patients and its correlation with survival. Nutr Cancer. 2006;55(1):78-85. https://doi.org/10.1207/ s15327914nc5501_10

PMid:16965244

20. Orell-Kotikangas $H$, Österlund $P$, Saarilahti $K$, Ravasco $P$, Schwab U, Mäkitie AA. NRS-2002 for pre-treatment nutritional risk screening and nutritional status assessment in head and neck cancer patients. Support Care Cancer. 2015;23(6):1495-502. https://doi.org/10.1007/ s00520-014-2500-0

PMid:25370893

21. Donohoe CL, Ryan AM, Reynolds JV. Cancer cachexia: Mechanisms and clinical implications. Gastroenterol Res Pract. 2011;2011:601434.

PMid:21760776

22. Wang CS, Sun CF. C-reactive protein and malignancy: Clinicopathological association and therapeutic implication. Chang Gung Med J. 2009;32(5):471-82.

PMid:19840504

23. Chen HH, Wang HM, Fan KH, Lin CY, Yen TC, Liao CT, et al Pre-treatment levels of $\mathrm{C}$-reactive protein and squamous cell carcinoma antigen for predicting the aggressiveness of pharyngolaryngeal carcinoma. PLoS One. 2013;8:e55327. https://doi.org/10.1371/journal.pone.0055327

PMid:23383155

24. Allin $\mathrm{KH}$, Nordestgaard BG. Elevated C-reactive protein in the diagnosis, prognosis, and cause of cancer. Crit Rev Clin Lab Sci. 2011;48(4):155-70. https://doi.org/10.3109/10408363.2011.599831 PMid:22035340

25. Ingle PV, Patel DM. C-reactive protein in various disease condition-an overview. Asian J Pharm Clin Res. 2011;4:9-13.

26. Takenaka $Y$, Yamamoto $M$, Nakahara $S$, Yamamoto $Y$, Yasui T, Hanamoto A, et al. Factors associated with malnutrition in patients with head and neck cancer. Acta Otolaryngol. 2014;134(10):1079-85. https://doi.org/10.3109/00016489. 2014.906750

PMid:25131392

27. Yoshida T, Delafontaine P. Mechanisms of cachexia in chronic disease states. Am J Med Sci. 2015;350(4):250-6. https://doi. 
org/10.1097/MAJ.0000000000000511

PMid:26083652

28. Lee S, Choe JW, Kim HK, Sung J. High-Sensitivity C-reactive protein and cancer. J Epidemiol. 2011;21(3):161-8. https://doi. org/10.2188/jea.je20100128

PMid:21368452

29. de Lima KV, Maio R. Nutritional status, systemic inflammation and prognosis of patients with gastrointestinal cancer. Nutr Hosp. 2012;27(3):707-14. https://doi.org/10.3305/ $\mathrm{nh} / 2012.27 .3 .5567$

PMid:23114934
30. Capuano G, Gentile PC, Bianciardi F, Tosti M, Palladino A, D Palma M. Prevalence and influence of malnutrition on quality of life and performance status in patients with locally advanced head and neck cancer before treatment. Support Care Cancer. 2010;18:433-7. https://doi.org/10.1007/s00520-009-0681-8

PMid:19562384

31. Santarpia L, Contaldo F, Pasanisi F. Nutritional screening and early treatment of malnutrition in cancer patients. J Cachexia Sarcopenia Muscle. 2011;2(1):27-35. https://doi.org/10.1007/ s13539-011-0022-x

PMid:21475618 